\title{
English-Indonesian Translation Method of Book's Glossary
}

\author{
Hastin Xirera, Abdul Muth'im, and Nasrullah \\ Universitas Lambung Mangkurat, Banjarmasin, Indonesia \\ Universitas Lambung Mangkurat, Banjarmasin, Indonesia \\ Universitas Lambung Mangkurat, Banjarmasin, Indonesia \\ *Corresponding Author: nasrullah01@ulm.ac.id
}

\begin{abstract}
Translation is an adjustment idea of one language to a different language equitably. In doing a translation, a translator needs to apply some methods to produce an acceptable translation. Plenty of researches on translation method have been administered. However, translation method research on a book's glossary is ostensibly still underresearched in translation studies. So that, to fill in this gap, this research aimed at figuring out and describing the methods of English-Indonesian translation used in the book's glossary "An Introduction: Theories of Learning 7th Edition Book". This research exerted a qualitative method. The objects of this research were An Introduction: Theories of Learning 7th Edition Book and its Indonesian version Theories of Learning: Teori Pembelajaran Edisi ke-7 based on Newmark's translation methods. The data was geared by documentation. Afterward, researcher classified the data suited to the determined table of instrument as a researcher tool in data collection. Furthermore, after elaborating the data, researcher analysed it descriptively. The result showed that there were five out of eight translation methods applied by the translator. Three of them are concentrated on source text comprising semantic translation, literal translation, and faithful translation. While two of those are concentrated on target text, namely free translation and communicative translation.
\end{abstract}

Keywords: book, English into Indonesian translation, glossary, theories of learning, translation method

\section{INTRODUCTION}

There exist lots of languages in this world. Every country has its own language, even more than one language. Language is required for humans as social creatures to switch information. For this reason, it is also used as a communication tool, it refers to making certain of things in the world (Shifa, 2013). Through language, human express feelings and ideas. There are two ways to relay the feelings and ideas, which are spoken and written. Spoken language includes monolog, dialog, oration, presentation, etc. Written language includes message, letter, news, article, brochure, story, novel, book, etc.

The multifariousness of languages in every country of the world may induce a predicament, especially communication in written language because it is hard to clarify the misunderstanding directly like in spoken language. Since English is proclaimed as lingua franca, it is used in all over the world. In Indonesia, English is recognized as a foreign language meaning that English is not a prior language to learn. That is why a lot of Indonesian people cannot grasp English well. However, a lot of news and information are delivered in English, consequently, they derive very little knowledge. Translation arises as the problem-solving for 
this problem. Translation is redesigning the equivalent meaning of a message from the initial language (SL) into a different language (TL) in written, so that the message will be delivered well to the receiver. Furthermore, Savory (1959) explained that a translation is a bridge of the difference between space and time.

Aiming to get a readable and understandable translation, a translator should be careful to identify the SL into the TL when converting the idea of the message. A translator must realize many different things from both languages. A translator provides the compatible words or sentences to convey the SL into TL, so that all people with different background knowledge of a particular language will easily absorb the information. In translating process, a translator often encounters several intricacies, which are: (1) intricacies in analysing and understanding the SL, (2) intricacies in transferring process and finding the equivalents in TL, (3) intricacies in getting best result of translation because hard to restructure the transferred material (Soenarno in Shifa, 2013). Dealing with these, a translator has to determine an opportune method in translation to deliver a worthy translation.

There is major dissimilarity between literary and non-literary works in translating both of them. The works of literary are aligned in human beings (physical characteristics, natural and climatic background) and concerned with the imagination world. On the other hand, the works of non-literary elucidated the actual fact, upgraded and modified by human intellectuality. Translating non-literary works like a scientific book is not easy, a translator must have particular qualities. Nababan confirmed that someone's competence in translation will support him to come to be a professional translator and competent in their field (2008).

A book entitled An Introduction to Theories of Learning: 7th Edition written by B. R. Hergenhahn and Matthew H. Olson (2001) has been widely used as a reference book in the educational field by a lot of academicians, educational practitioners, and students from all over the world. This book was firstly published in 1996 and has been printed several times until now. The extensive and massive use of this book made it has been translated into variety languages, including Indonesian. As one of the main reference books in Indonesia, it has been translated into Indonesian to make all of the readers have more understanding. It has been translated by Triwibowo Budi Santoso with the title is Theories of Learning (Teori Belajar): Edisi Ketujuh published in 2008 by Kencana Prenada Media Group, Jakarta.

Susie Kusumayanthi and Tiara Fitria (2020) had administered a research on non-literary work with aim to find out the type of translation method of college students in Cimahi used to translate an article from English into Indonesia. The researcher distinguished this book as the product of translation and studies as the object of translation research. The researcher is captivated in the translation topic for analyzing what translation method used in the book's glossary in An Introduction: Theories of Learning 7th Edition Book into Teori Belajar: Edisi Ketujuh from English into Indonesian derived from Newmark's (1988) methods of translation theories. The researcher elects to research on glossary because the object of the research is scarcely used in the previous researches, this research explores more in this area. The researcher determines Newmark's (1988) theory about translation methods because Newmark (1988) serves a clear view about the product of translation, and is easily considerable. Furthermore, Newmark's (1988) translation method theory has been used as a measurement in translation quality which includes Word for Word Translation, Literal Translation, Faithful Translation, Semantic Translation, Adaptation Translation, Free Translation, and Communicative Translation. By the provided theories above, the research title is EnglishIndonesian Translation Method of Book's Glossary "An Introduction: Theories of Learning 7th Edition Book". 


\section{DEFINITION OF TRANSLATION}

Many experts gave their thoughts and opinions on what translation is. A definition of translation proposed by Catford (1965) that translation is a language operation: a process of substituting a text in one language for a text in a different language. The other expert, Newmark (1988) designated that translation is the super ordinate term for revising the meaning of any source language's utterance to the target language. Then, according to Munday (2008), the term of translation has some meanings, it may implies a general subject field, a product, or a process that is a translator (a person who is doing the translation) changes original written text (ST=source text) into a written text (TT=target text) in another language. Another definition from Kridalaksana (1985) that translation is rearranging the mandate from source language to the intended language by unveiling its meaning then its language style. Larson (1989) contributed a definition of translation that translation means reconstructing the same meaning by using the definite lexis and grammatical structure in the target language and its cultural context. To sum up, translation is a term that is used to define changing text or utterance meaning from one language into another language by revealing the similar meaning in good structure and context of the target language.

\section{THE KINDS OF TRANSLATION}

Roman Jakobson, Russo-American structuralist, explained that there are categories of translation (Newmark, 1988). Jakobson's categories are as follows: 1) Intralingual translation is also called rewording is the meaning interpretation of other signs with the same language. It is rephrasing, summarizing or rewriting a text in the language. 2) Interlingual translation is also labelled as translation proper is the meaning interpretation of verbal signs with some other different language. It occurs between two different verbal languages. 3) Intersemiotic translation is also known as transmutation is a meaning interpretation of verbal signs with signs of non-verbal sign systems. A written text is translated into other forms excluding written, for example music, film, or painting.

Drew on the purpose of translation, Brislin (1976) categorized translation into these following: 1) Pragmatic translation, it implies the translation of a message with a concentration in accuracy of the information from the source language form. 2) Aesthetic-poetic translation, it signifies the translation where the translator witnesses the affection, emotion, and sensibility of an authentic form, the beauteous version applied by the initial writer, along with any notion found in a message. The instances of this translation are found on heroic couplet, dramatic dialogue, sonnet, rhyme, and novel. 3) Ethnographic translation, sensitive translators are required on how the way of words are played and must know how the words fit in culturally. The purpose is to explicate the cultural context of the source language and target language versions. 4) Linguistic Translation, it is reported on compatible meanings of the component morphemes of the grammatical structure and the source language. For instance, is the language utilized in programs found at a computer and translation's machine.

Brislin continued that there are two translation types that are principally built from the kinds of texts, those are factual translation and literary translation. Factual translation specifies translating to reveal information with accuracy, exclusive of embracing the translator's affection or sensibility, only focus on the actual proven facts such as translating scientific areas, books, reports, journals, newspapers, etc. Literary translation expresses the translation of 
artistry works, where the translator embraces his or her affection or feeling and it tends to be personalised, for instance the translation of poems, plays, novels, etc.

\section{TRANSLATION METHODS}

A definition of method in translation is proposed by Machali (2000), that is, method is a way of doing a translation. Hartono (2017) added a description that translation method greatly influences the translation result. The result of text translation is extensively dictated by the translation method picked by the translator suited to the intention, goal and decision of the translator will influence the results of a text translation as a complete one. Peter Newmark (1988) proposed in his book entitled A Textbook of Translation that there are eight methods that could be used in translation in two perspectives. The initial perspective emphasizes on source language (SL), where a translator keeps up with what is general could be in the origin language, such as the form, the lexicon, and the culture of the SL. The following perspective emphasizes the target language (TL), where a translator tags along the TL such as the form, the lexicon, and the culture intending to construct the readers grasp the translation text further.

The initial perspective comprises: 1) word-for-word, the SL words are translated into the TL with one word one word singly by holding the most common meaning. The SL wordorder is conserved. Cultural words are translated directly as literal as it, for to the meaning is out of context;2) literal translation, translating the SL lexical words singly, but converting grammatical constructions to the nearest TL equivalent. Hence the lexical words are translated singly, consequently the meaning is out of context;(3) faithful, this method strives to focus on the goal and the realization of a text intended by the SL writer, where it searches for the TL original grammatical structures in a exact and precise contextual meaning. Words that contain culture are translated, but deviations in terms of grammar and word choice are still conserved. It strives to be wholly faithful to the intentions and the text-realisation of the SL writer, so that sometimes it produces strange and stiff translation; and 4) semantic translation, The focus of this method is translating the SL text into the proper meaning and aesthetic values that are the beautifulness and the naturalness, and in the last product there are no repetition jars, assonance, or word-play. It may translate less important cultural words by culturally neutral or functional terms, but not by cultural equivalents.

The following perspective encompasses:1) adaptation, this is the 'freest' and the closest form to TL of translation. The SL culture transformed into the SL culture in rewritten text. It applies for comedy, drama, and poetry by maintaining theme, characters, and story line, where those are translated and rewrote into dramatist or poet; 2) free, paraphrasing skill is needed in this method. Reproduce the substance of the original text into the target language much longer or shorter without notice of its original form, which allows to add some additional information. This method does not pay attention to manner and the originality of SL text, it reproduces matter and content; 3) idiomatic, this method strives to replicate the 'message' in new nuances of meaning by preferring idioms and colloquialisms, common spoken expressions; and 4) communicative translation, The acceptable and comprehensible language are the aims of this method as a social function of a language. This method tries to translate accurate contextual meaning, so the result of this translation is natural, clear, and brief like it is not a translation result. All of them are aligned like V letter from the easiest methods at the top until hardest methods at the bottom, which shows that the closer to the bottom the better translation to understand since it is closed to the target language so as to the readers cognize it. Those methods described in the V diagram as follows (Newmark; 1988). 


\begin{tabular}{|c|c|}
\hline Source Language Emphasis & Target Language Emphasis \\
\hline Word-for-word & Adaptation \\
\hline Literal & free \\
\hline Faithful & idiomatic \\
\hline Semantic & communicative \\
\hline
\end{tabular}

FIGURE 2 Translation Method by Newmark

\section{BOOK TRANSLATION}

Non-literary work is 'all the ease' (Tytler, 1791). Essentially, the domain of non-literary translation is concerned with the actual truth, which empowers the narrative of the origin language text, as reflected in the target language text, to coincide with the real world's reality (Newmark, 2003). Book is one of non-literary work products.

\section{GLOSSARY}

A translator needs a dictionary, encyclopedia, or glossary to overcome difficulties, such as not understand a word, sentence, or paragraph meaning, and understanding but hard to translate (Afrila et al., 2019). Glossary is one of the lexical aid tools for a translator to translate. Glossary may contain other metadata, such as the definition, context, part of speech, and review date/approval (Lionbridge, 2013). Glossary will enhance consistency, produce efficient time, and reduce the overall cost of a translator. It helps to eliminate uncertainty in the translation process (Lionbridge, 2013).

\section{METHOD}

This research exerted descriptive qualitative research to figure out and describe what methods applied by the translator in translating non-literary work's glossary "An Introduction: Theories of Learning 7th Edition Book". According to Fraenkel and Wallen (2009), qualitative research is addressing on the natural setting as the direct supply of data and the researcher is the leading instrument. In addition, Dornyei (2007) claimed that qualitative research is crucially interpretive, that is the researcher's subjective interpretation of the data is the research result. The description of the translation study is broken into three parts derived from the orientation types, which are product-oriented, function-oriented, and process-oriented translation study (Holmes in Sorvali, 1996). In this research, the researcher tried to expose more information and to apprehend the circumstance of the research object about what translation method was used, then deliver the finding of this research in the form of description about what the researcher discovered.

The research objects of this research were the glossary terms related to predominantly cognitive theories of the book "An Introduction: Theories of Learning: 7th Edition" written by B. R. Hergenhahn and Matthew H. Olson (2001) published by Prentice Hall, and its Indonesian translated version "Theories of Learning (Teori Belajar): Edisi Ketujuh" translated by Triwibowo Budi Santoso (2008) distrubuted by Kencana Prenada Media Group.

The whole process a researcher accumulates the data is described as instrumentation (Fraenkel \& Wallen, 2009). Data is the answer to the question. Therefore, to gain accurate data, 
the researcher requires to decide the appropriate instrumentation (Muth'im, 2020). In this research, the researcher as the primer instrument by applying documentation and table as tools in data collection. Hammersley and Atkinson (1995) disclosed that in a research process, the researcher acts as an active respondent. Researchers activate their sensory organs to fathom the research objects, reflecting them in their cognition, then adapt them to be interpreted (Turato, 2005).

In this research, the researcher has some roles, which are: 1) As an observer, the researcher read the whole glossary of the book. Documentation is enacted as the instrument tool. Sudjana (1988) declared that documentation was the instrument of accumulating data in which applied to assemble individual behaviors or the process of the activity which was regarded in simulation or actual condition. This instrumentation was purposed to get data of the translation method. Through observing the document, all data collected was in the form of sentences from the glossary of the two books that tabulated into a table. Afterward, the researcher will categorize all data from documentation. 2) As a data collector, the researcher accumulates the certain data from the research object based on the scope of the research, then organizes it on a table. 3) As an analyser, the researcher analyses the data and classifies it based on the translation method proffered by Newmark. The instrument tool of data gathering used is table. The data will be collected by identifying the translation method used in the book based on certain classifications on a table. The classifications on a table used in this research based on eight translation methods proposed by Peter Newmark. 4) As a data reporter, where the researcher reports the data analysis in detailed description.

\section{FINDINGS AND DISCUSSION}

The researcher analyzed the translation method applied by the translator. The analyzing developed on the Newmark's theory (1988). There are eight translation methods from the theory, specifically word-for-word translation, literal translation, faithful translation, semantic translation, adaptation translation, free translation, idiomatic translation and communicative translation. Total data in words, phrasal, and sentences is 70 , which is parsed from 50 terms in glossary. Those then were analyzed per words, phrases, or sentences by the researcher for the purpose of knowing the translation methods used in the book's glossary of An Introduction: Theories of Learning 7th Edition Book to its Indonesian translation. Elicited from the findings in the book's glossary of An Introduction: Theories of Learning 7th Edition Book to Indonesian translation showed that the translator only applied five translation methods out of eight translation methods by Newmark's theory (1988) in translating, they are concentrated on source text: Semantic Translation (23 data), Literal Translation (22 data), and Faithful Translation (13 data); and concentrated in target text: Free Translation (9 data), and Communicative Translation ( 3 data).

Molina and Albir (2002) declared that method of translation attributes to the way of a certain process of translation that is transported out in terminology of the translator's goal, whereupon it can be assumed that translation method has leaning to a way applied by a translator agree with the goal. Subsequently, translation method fundamentally affects the translation result. Meaning that translation text is determined by the translation method since the meaning, aim, and the translator's intuition influence the whole translation text completely. The translator used more semantic translation method compared to the other eight methods. It implicates that the translator has leaning to use semantic translation method because the translator tends to keep source language (SL) emphasis, take account of the aesthetic quality and deal with apt meaning, and translate less crucial cultural words into functional 
terminologies but not by cultural equivalents. Newmark's semantic translation designs to retain the original structure in translation and to recreate the initial circumstantial meaning as densely as possible, can help the TL readers to grasp the text's message but still maintain the sentence structure of the ST or the form of the ST. The translator did not apply of word-for-word method, adaptation method and idiomatic translation method which indicate that the translator avoided to translate the words singly by the most common meaning and translate the cultural words literally which make the meaning is out of context, the translator did not rewrite the text or reproduced the 'message' in new atmospheres of meaning by preferring common spoken expressions and idioms, and did not convert the SL culture into the TL culture, also mostly the translator did not emphasized on the target Language (TL) in an attempt to keep the cultural terms of the theories of the book.

The writer displayed the frequency of translation method used. The first step, the researcher identified the translation method. Then, classified it into the category of translation method. The researcher compiled the findings as follows.

TABLE 1. Findings

\begin{tabular}{ccc}
\hline Number & Translation Method & Frequency \\
\hline 1 & Semantic & 23 \\
2 & Literal & 22 \\
3 & Faithful & 13 \\
4 & Free & 9 \\
5 & Communicative & 3 \\
& Total & 70 \\
\hline
\end{tabular}

Semantic Translation. The concern of this method is translating the SL text into the proper meaning with the beautifulness and the naturalness. Machali (2000) elucidated that this translation method might perhaps translate less crucial cultural words by functional terminology, that is easy to comprehend.

TABLE 2. Datum 11

\begin{tabular}{cll}
\hline Datum Number & \multicolumn{1}{c}{ English } & \multicolumn{1}{c}{ Indonesian } \\
\hline 11 & $\begin{array}{l}\text { Delayed modeling: The case } \\
\text { in which an observer does not } \\
\text { display what .... }\end{array}$ & $\begin{array}{l}\text { Delayed modeling: Kasus } \\
\text { dimana seorang pengamat } \\
\end{array}$ \\
\end{tabular}

In this case, the translator applied semantic translation because the target text prioritizes the aesthetic value and compromise the meaning grammatically correct, but still maintaining ST messages. It is proven in the word 'display' is translated into 'melakukan' not translated literally into 'menampilkan'. The translator tried to choose the beautiful and appropriate meaning. Moreover, the translator retained the structure of the ST in the English translation by not translating 'freely' and making any changes in the sentence structure in TT. In this case, there is a compromise between achieving accuracy and maintaining ST attributes. Retaining the sentence structure of the ST in the TT can be considered as one of the characteristics of semantic translation method. This is why, it can be inferred that the sentence is translated by using semantic translation method. 
Literal Translation. The lexical words are translated singly, consequently sometimes it produces meaningless and unusual translation (Machali, 2000). A translator translates source text word-for-word first, then adjusts the target text's grammatical structure (Hartono, 2017).

TABLE 3. Datum 5

\begin{tabular}{clll}
\hline Datum Number & \multicolumn{1}{c}{ English } & \multicolumn{2}{c}{ Indonesian } \\
\hline 5 & $\begin{array}{l}\text { Attentional processes: } \ldots . \\
\text { during observational learning. }\end{array}$ & $\begin{array}{l}\text { Attentional } \\
\text { selama } \\
\text { observasional. }\end{array}$ & $\begin{array}{r}\text { processes: .... } \\
\text { belajar }\end{array}$ \\
\hline
\end{tabular}

The translator used literal translation method because there is transmutation among the grammatical composition of the SL and the TL. The lexical words are translated singly, 'during' is translated into 'selama', 'observational' is translated into 'observasional', and 'learning' is translated into 'belajar'. It showed that the translator began the translation word by word, then repaired the grammatical composition among the SL and the TL, so that the datum 'during observational learning' which is translated into 'selama belajar observasional' not 'selama observasional belajar'. It can be inferred that the datum above suits to literal translation.

Faithful Translation. This method triggers to focus on the goal and the realization of a text proposed by the SL writer, where it seeks the TL original grammatical structures in an exact contextual meaning. It struggles to be entirely faithful to the goals proposed by the SL writer and the text-accomplishment of the SL writer. Hartono (2017) added that by using this translation method, the translator strongly maintains the aspects of format, form, metaphorical forms, and term forms, in such a way that the reader can see the faithfulness of its form in the target language entirely, even though the translation results are unusual or unknown. Words that contain culture are translated, but deviations in grammar's terms and word choice are still conserved.

TABLE 4. Datum 1

\begin{tabular}{|c|c|c|}
\hline Datum Number & English & Indonesian \\
\hline 1 & modeling: & modeling: \\
\hline & $\begin{array}{l}\text {...extracted, the rule or } \\
\text { principle can be applied .... }\end{array}$ & $\begin{array}{ll}\text {...diekstrak, aturan atau } \\
\text { prinsip bisa diaplikasikan }\end{array}$ \\
\hline
\end{tabular}

The proofs that the translator applied faithful translation were on the source language emphasis and the cultural terms were conserved. The reason why the translator applied this method since there is no other word that could compel the word's meaning of the source language text plainly. Consequently, it was translated exactly like the SL. The translator struggles to translate the meaning of the source text with the aim of trying to deliver the intention of the writer. Yet, the translation maintains the grammar of the SL and the lexicon that swerve from the TL norms. The source text 'extracted' is translated into 'diekstrak' that is equal to its literal meaning in the target language. Thorough fully, the sentence above contained the faithful translation because from the transmutation among the source text and the target text reproduced the exact contextual meaning of the SL within the limitations of the TL grammatical constructions, the translator attempted to be totally faithful to the aims and the text-realisation of the SL writer, which produced the rigid and weird translation.

Free Translation. Paraphrasing capability is required in this method. It reproduces the substance of the initial text into the target language much longer or shorter without notice to 
its original form, it allows to append some additional information. This method remakes matter and content, so that the content or message of the author of the source text will be more obviously acquired by target language readers. Consequently, the translation is pleonastic, even though the result of the translation looks like it is not a translation (Hartono, 2017).

TABLE 5. Datum 43

\begin{tabular}{|c|c|c|}
\hline Datum Number & English & Indonesian \\
\hline \multirow[t]{2}{*}{43} & Self-regulated & Self-regulated \\
\hline & $\begin{array}{l}\text { Behavior that is regulated by } \\
\text { one's own performance } \\
\text { standards, moral codes, or } \\
\text { imagination. }\end{array}$ & $\begin{array}{l}\text { Perilaku yang diatur oleh } \\
\text { standar kinerja sendiri, kode } \\
\text { moral sendiri atau imajinasi } \\
\text { sendiri. }\end{array}$ \\
\hline
\end{tabular}

The datum above used free translation because the target language is longer than the source language. The source text 'Behavior that is regulated by one's own performance standards, moral codes, or imagination' should be translated into 'Perilaku yang diatur oleh standar kinerja, kode moral atau imajinasi seseorang sendiri', but the translator translated it into 'Perilaku yang diatur oleh standar kinerja sendiri, kode moral sendiri atau imajinasi sendiri'. The translator repeated 'seperti' three times and did not translated 'one's'. The translators applied free translation method because the source language is not transferred perfectly to the TL and the translator appended explanation in target language with the aim of the readers will receive it undeniably. It showed that the datum above deals with free translation method.

Communicative Translation. The acceptable and comprehensible language are the targets of this method as a social function of a language. This method strives to translate exact contextual idea, so that the result of this translation is natural, clear, and brief akin to it is not a translation outcome. Nababan (2003) defined that this method basically emphasizes on shifting the message. This method prioritizes TL readers who do not expect any obstacles and uncertainty in the translated text. It is also very concerned about the translation language effectiveness.

TABLE 6. Datum 37

\begin{tabular}{cll}
\hline Datum Number & \multicolumn{1}{c}{ English } & \multicolumn{1}{c}{ Indonesian } \\
\hline 37 & Real self-efficacy: What a & Real self-efficacy: Apa yang \\
& person is actually capable of & sesungguhnya mampu \\
& accomplishing: may or may & dilakukan ran seseorang; \\
& not correspond to perceived & mungkin berhubungan \\
& self-efficacy. & dengan persepsi tentang \\
& & kecakapan diri atau mungkin \\
& & juga tidak. \\
\hline
\end{tabular}

The result of the translation is natural and clear because the translator translated it by noticing to the social function in order for the readers to require it effortlessly. This is fitted with the communicative method, where the translator aimed to bring out the translation as natural as possible to the target language. The translator wanted the readers to grasp the message well when they read it for the first time. The explanation in target text 'tentang' and 'juga' are attached in the target text to serve the obvious readership and easily comprehend. The translator emphasized on the target language that is why the translator is not bounded by the source language's grammatical constructions and literal meaning. 


\section{CONCLUSION}

It can be concluded derived from the data analysis result that the translation methods used in translating book's glossary from English into Indonesian that there were five out of eight translation methods of Newmark's theory. There were three of four methods that concentrated to the source text, those are semantic translation, literal translation, and faithful translation. Whilst in, there are two of four methods that concentrated to the target text, they are free and communicative translation. Meanwhile, the word-for-word, adaptation translation and idiomatic translation were not found. Most of the methods found are emphasizing on the source text with the dominant one is semantic translation. It showed that the translator intended to maintain some source text cultural terms related to the theory of learning, but tried to serve it in an informative and correct meaning by still retaining the source language grammatical structure.

\section{ACKNOWLEDGEMENT}

The authors praise to Allah SWT who gives His blessings from the beginning to the end of this project. This study will not be completed without the assistance, encouragement, inspiration, and motivation of many people, whether or not they are directly related to this research.

\section{REFERENCES}

Afrila, M., Emzir, \& Anwar, M. (2019). Metode Penerjemahan Istilah-Istilah Bidang Ilmu Linguistik dari Bahasa Inggris ke dalam Bahasa Indonesia. 1st National Seminar of PBI (English Language Education). 978-602-6779-26-7.

Brislin, R.W. (1976). Translation: Application and Research. New York: Gardner Press.

Bull, V. (2011). Oxford: Learner's Pocket Dictionary (4th ed.) New York: Oxford University Press.

Catford, J. C. (1965). A Linguistic Theory of Translation. London: Oxford University Press.

Dornyei, Z. (2007). Research Methods in Applied Linguistics. Oxford: Oxford University Press.

Fraenkel, J. R., \& Wallen, N. E. (2009). How to Design and Evaluate Research in Education (7th ed.). New York: The McGraw-Hill.

Ginting, D., F., Nainggolan, R., M., \& Mono, U. (2018). Translation Methods in Reader's Digest Magazine by Students' of English Department at HKBP Nommensen University (thesis). University of Sumatera Utara, Medan, Indonesia.

Guion, L., Diehl, D., \& McDonald, D. (2002). Triangulation: Establishing the Validity of Qualitative Studies. The Institute of Food and Agricultural Sciences. FCS6014.

Hammersley M, \& Atkinson P. (1995). Ethnography: Principles in Practice 2. New York: Routledge.

Hartono, R. (2017). Pengantar Ilmu Menerjemah. Semarang: Cipta Prima Nusantara.

Hayati, H. (2014). Dynamic Equivalence In Bahasa Indonesia-English Translational Texts of Public Signs (thesis). State University of Yogyakarta, Yogyakarta, Indonesia.

Hergenhahn, B. R., \& Olson, M. H. (2001). An Introduction to Theories of Learning (7th ed). New Jersey: Prentice Hall.

Hergenhahn, B. R., \& Olson, M. H. (2008). Theories of Learning (Teori Belajar) (7th ed). (Sasono, T. B., Terjemahan). Jakarta: Kencana Prenada Media Group. 
Kridalaksana, H. (1985). Tata Bahasa Deskripsi Bahasa Indonesia: Sintaksis. Jakarta: Pusat Pembinaan dan Pengembangan Bahasa Departemen Pendidikan dan Kebudayaan.

Kusumayanthi, S., \& Fitria, T. (2020). An Analysis of Translation Method Used by College Students in Translating An Article. English Journal Literacy Utama. 2654-5284.

Larson, M. (1989). Penerjemahan Berdasarkan Makna: Pedoman untuk Pemadanan Antarbahasa. Jakarta: ARCAN.

Lionbridge. (2013). What is a Translation Glossary? [Brochure]. (2013). Waltham: Lionbridge.

Machali, R. (2000). Pedoman bagi Penerjemah. Jakarta: Grasindo.

Molina, L. \& Albir A.H. (2002). Translation Technique Revisited: A Dynamic and Functional Approach. Barcelona: Universitat Autònoma de Barcelona.

Munday, J. (2008). Introducing Translation Studies: Theories and applications 2nd Edition. New York: Routledge.

Muth'im, A. (2020). Pengantar Penelitian Pendidikan Bahasa. Malang: IRDH.

Nababan, M. R. (2003). Teori Menerjemah Bahasa Inggris. Yogyakarta: Pustaka Pelajar.

Nababan, M. R. (2008). Kompetensi Penerjemahan dan Dampaknya pada Kualitas Terjemahan. Pidato Pengukuhan Guru Besar Bidang Penerjemahan Universitas Sebelas Maret. Surakarta: Universitas Sebelas Maret.

Newmark, P. (1988). A Textbook of Translation. New York: Prentice Hall.

Newmark, P. (2003). Non-literary in the Light of Literary Translation. Semantic Scholar. 157064212.

Noori, A. (2018). Glossary of Research Terms. Kabul University Journal. 10.13140/RG.2.2.29067.18724.

Nurhanifah, N., D. (2019). An Analysis of English-Indonesian Translation Methods in Products' Label (thesis). Muhammadiyah University of Surakarta, Surakarta, Indonesia.

Pamungkas, M. E. (2020). Translation Methods in Political Speeches: A Case Study of English Translation of President Joko Widodo's Inaugural Address. Paradigma Jurnal Kajian Budaya. 132-146.

Savory, T. R. (1959). The Art of Translation. London: Cape.

Shifa, M., L. (2013). Translation Methods In "A Walk to Remember" Novel Translated Into "Kan Kukenang Selalu" (thesis). Dian Nuswantoro University, Semarang, Indonesia.

Sipayung, K. M. (2018). The Impact of Translation Shift and Method on Translation Accuracy Found at Bilingual History Textbook. Jurnal Humaniora. doi.org/102216/jh.v29i3.27754.

Sorvali, I. (1996). Translation Studies in A New Perspective. Frankfurt: Peter Lang.

Turato E. R. (2005). Qualitative and Quantitative Methods in Health: Definitions, Differences and Research Subjects. Revista de Saude Publica. 39(3):507-514.

Tytler, A. F. (1791). Essay on the Principles of Translation. Amsterdam: John Benjamins.

UNAIDS. (2010). An Introduction to Triangulation [Brochure]. Geneva: UNAIDS.

Wiersma, W. (1995). Research Methods in Education: An Introduction. Boston: Allyn and Bacon. 